\title{
THE IMAGE OF WISE WOMAN IN A LITERARY TEXT (BASED ON THE NOVEL „THE DEVIL WEARS PRADA” BY LAUREN WEISBERGER)
}

\author{
Oksana Babelyuk \\ Professor, PhD, Lviv State University of Life Safety, \\ e-mail: babelyuko@gmail.com, orcid.org/0000-0003-4837-1225, Ukraine \\ Andrii Galaidin \\ MA, Polonia University in Częstochowa, \\ e-mail: a.galaidin@live.ap.edu.pl, orcid.org/0000-0002-5236-1495, Poland
}

\begin{abstract}
The article is focused on main characteristics of a new postmodern genre chick lit, namely on the image of a wise woman in modern literature. The analysis is based on the novel "The Devil Wears Prada" by Lauren Weisberger, as well as on the classification of literary images that occur in contemporary Poetics. The authors assume that chick lit presents a new type of a woman in postmodern literature - a wise woman. It is defined that lexical means and stylistic devices, such as metaphors, personifications, hyperboles, and rhetorical questions create the image of wise woman as the one who is aspiring to a career, realising herself not only in the area of family, but mainly in the area of professional life, and at the same time does not forget to take care of herself in the struggle of different duties. It is stressed that this image has not always meant an independent feminist woman, but has in fact undergone great transformations from a feminine stereotype of a devoted woman to a wise woman due to rapid changes that have taken place recently in women's lives.
\end{abstract}

Keywords: chick lit, image, the image of wise woman, literary text, lexical means, stylistic devices.

DOI: http://dx.doi.org/10.23856/3706

\section{Introduction}

Nowadays we are living at a time when women's rights have been made practically equal to those of men. Women are often university graduates, they are valued employees. The stereotype of a devoted woman as a person who serves and cares for a man, as well as for the home and children, is increasingly disappearing.

Many women with their own families are professionally fulfilled, striving for selfrealization and self-improvement. Nowadays, women have their own rights but also interests, which give them a break from their daily routines. As a result, more and more literature is written by women, and dedicated for women to read.

The leading genre that emerged in the 1990s is chick lit. Usually, the content of the story focuses on a young woman in her 20 s or 30 s, active in a professional career, often working on a high position. The protagonist focuses mainly on work, but after hours she tries to find time for herself. She dreams of an ideal partner, she goes dating, but the relationship is not the most important for her, she is by no means able to cope without a man. This is a new image of an independent wise woman, who though is focused on the family but at the same time also on herself. She has time for both her family and herself. After work, she often pursues her interests and passions. That's why, books written by women and for women can be found on the shelves of bookstores more and more often. 
In this article we would like to draw attention to a relatively new postmodern literary genre which is called the chick lit - often perceived as typically feminine. The aim of the article is to determine the image of a wise woman on the basis of one of the most famous novel of the lit chick genre -,,The Devil Wears Prada” by Lauren Weisberger. Besides, we'd like to analyse the most frequently used lexical means and stylistic devises which work together on the creation of the image of a wise woman in a postmodern literary text.

\section{The chick lit as a postmodern literary genre: theoretical assumptions}

Chick lit is a relatively new postmodern literary genre. The term "chick lit" describes a form of commercial women's fiction which appeared in the 1990s. The books are considered to be written by women, for other women to read. Chick lit critics generally agreed that British author Catherine Alliott's The Old Girl Network (1994) was the start of the chick lit genre and the inspiration for Helen Fielding's Bridget Jones's Diary (1996) which was wildly popular and is the "ur-text" of chick lit. The milestone in the genre is definitely Bridget Jones's Diary by Helen Fielding (1996), as well as Sex and the City by Candace Bushnell (1997).

Although the genre itself seems to be a new concept in the frame of postmodern poetics. Some writers connected its appearance with the nineteenth century novels such as Charlotte Bronte's Jane Eyre, and Jane Austen's Nortanger Abbey. H. Fielding herself admitted that Austen's Pride and Prejudice was the inspiration to write about Bridget. The biggest difference between today's chick lit and the earlier novels about women is the use of humour, a distinctive, more open attitude toward sex and consumerism (Smith, 2008: 7-8).

The derivation chick lit is made of the words chick, which in slang means a young woman, and lit, which is a short form of the word literature. It usually tells the story of young women, aged 20 or 30, living in urban areas. The main heroine is professionally active, most often employed in PR, media and publishing. She often has a partner but does not focus all her attention and time on him. She knows that she wants to be in a relationship, but it is not a necessity, because she is fulfilled and financially independent, she has friends to count on. After work, she has time to perfect herself, for example through beauty treatments, and time for pleasure such as shopping.

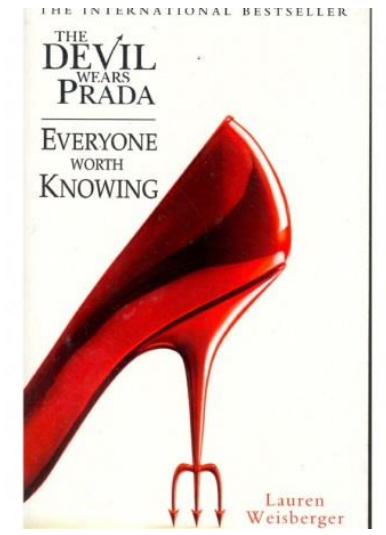

Figure 1. "The Devil Wears Prada" cover (Weisberger, 2003)

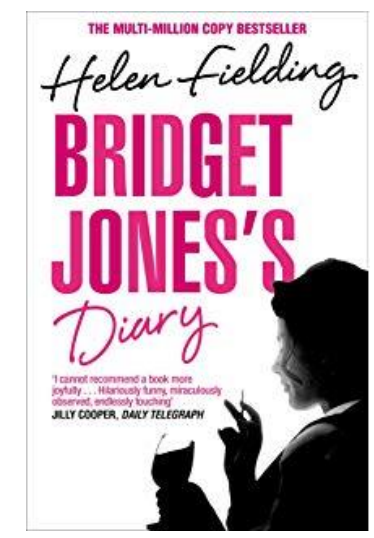

Figure 2. "Bridget Jones's Diary" cover (Fielding, 1996) 
Usually graphical stylistic devices of book-covers of this postmodern genre are typically girlish -- they have light shades of red, pink or purple. They show women's goodies such as a lipstick, heeled shoes or a glass of martini. All of them are intended to attract attention of the potential women-customers.

Although chick lit is a popular postmodern literary genre, especially among women, it is very controversial. While its readers and enthusiasts are enjoying and celebrating the genre, some others, less enthusiastic about it, are continuously trying to point the difference between valuable "serious" literature and "trivial" chick lit. Sometimes it can be written in a form of a diary (Bridget Jones's Diary), some use a kind of a confessional style, like e-mails, letters, or first-person narration (The Devil Wears Prada). Anyway, it should be remembered that this is a type of literary genre where you can certainly relax after a difficult day.

So we are experiencing a fourth wave of feminism, and romantic comedy novels, or chick lit, play a very impotant part in it.The genre of chick lit addresses issues of modern womanhood - from romantic relationships to female friendships to matters in the workplace in humorous and lighthearted ways. Its protagonists tended to be single, white, heterosexual, British and American women in their late twenties and early thirties, living in metropolitan areas. Although it sometimes includes romantic elements, chick lit is generally not considered a direct subcategory of the romance novel genre, because the heroine's relationship with her family or friends is often just as important as her romantic relationships.

\section{Classification of literary images in contemporary Poetics}

There are many possibilities to classify literary characters. One of them is a psychological aspect of the characters. It allows us to examine the behaviour, the personality and the transformation of the inner state of the characters. Sometimes we can also find some information about the author's psyche on the basis of his or her work. According to Carl Gustav Jung, a Swiss psychiatrist and psychoanalyst, there is a visible relation between literature and psychology:

"It is obvious enough that psychology, being the process of psychic processes, can be brought to bear upon the study of literature, for the human psyche is the womb of all sciences and arts. We may expect psychological research, on the one hand, to explain the formation of a work of art, and on the other to reveal the factors that make a person artistically creative" (Jung, 1930).

Although, both fields of study are related to each other, there is a difference in analysing them. In psychological analysis of literature the main subject of investigation is the behaviour of the characters, their motivations and speech. Linguistic analysis focuses on the stylistic and artistic value of the text, its poetical elements like the plot, characters and settings (Babelyuk, 2018).

According to the interrelation between literature and psychology, G.C. Jung developed the concept of "Psychology of the Unconsciousness". This theory assumes that the human psyche consists of both consciousness and unconsciousness. That is to say, the dynamic system and culture are created by our conscious thoughts, and the archetypal values are represented by unconsciousness (Babelyuk, 2018). If so, what is archetype then? The Oxford Concise Dictionary of Literary Terms defines archetype as:

"A symbol, theme, setting, or character-type that recurs in different times and places in myth, literature, folklore, dreams, and rituals so frequently or prominently as to suggest (to certain speculative psychologists and critics) that it embodies some essential element of 'universal' human experience” (Baldick, 2001: 19). 
Moreover, it gives examples of three stock characters: femme fatale, the hero, and the magician. Femme fatale is a woman considered to be sexually attractive, causing men to love her and therefore, is likely to ruin them (Collins Dictionary, 2020). The hero is a male character in a book, story, film or play, usually have good qualities and is known for doing something brave, good or new, thanks to what is generally admired by other people (Collins Dictionary, 2020). The magician is a person, especially men, who has some special magical powers (Collins Dictionary, 2020).

Another way of classifying characters is their influence on the story. E.M Forster (English prose writer, essayist and literary critic (Wikipedia: E. M. Forster, 2019)) defines them as round and flat characters. On this basis he claimed that "...it is only round people who are fit to perform tragically for any length of time and can move us to any feelings... they are capable of surprising us in a very convincing way" (Forster, 2005: 81).

Furthermore, we can talk about the characters according to the frequency of their appearance in the story. Here, we distinguish main, supporting and episodic characters. Simply, main characters are the most important ones in the story, have an impact on the evolution of events, their life happenings are the basis of a literary work. Supporting characters do not have too much influence on the development of events, but are apparently related to the main character. Episodic characters are associated with the main character, but appear rarely in the text, creating the background (Babelyuk, 2018).

Additionally, there is the most basic classification of literary characters, in which we divide them according to the value of good and evil in their behaviour. Here, we distinguish negative characters, faust, and positive characters (Babelyuk, 2018).

There are images of characters whose perception has not changed for centuries, but there are also those, whose meaning changes with the passage of time, in some sense adapting to the era. Although we live in civilized times, where most people are educated, stereotypes are still alive. Among them there are some that concern women.

Women's situations are reflected in literature in general, and in postmodern genres, in particular. So it is worth analysing it in order to gain an insight into their rights and duties throughout literary history. Nowadays, a modern, wise woman is not only devoted to family matters, but also works, educates herself and finds time for herself, which is perfectly presented in a postmodern genre of chick lit.

\section{Lexical means of revealing the image of a wise woman in a postmodern literary text}

Due to the fact that women currently occupy a different place in the society than in the past, also their environment and situations in which they participate have changed in postmodern society. They do not only take care of the home and children, but are professionally active, spending their time on their own development and realization. They have hobbies. Many women take care of their souls, but also their bodies by visiting fitness clubs, beauticians or hairdressers.

Such extensive transformations caused many changes in the modern women's vocabulary. Here we would like to focus on new words and phrases that appear in the statements of the protagonists of the analysed book "The Devil wears Prada" by Lauren Weisberger. We take into account mainly the names of brands, new types of clothes and their descriptions, and accessories. On this basis we can assume how the protagonist, a modern fame fatal woman, is dressed to work and in leisure time. They are one of the visual factors 
that help us define the key features of a modern woman. All textual quotations come from the book The Devil Wears Prada (Weisberger, 2003) by Lauren Weisberger.

- 'Bags and shoes I'd never seen on real people shouted Prada! Armani! Versace! From every surface”. (p. 8). Here we can see three nominations of famous brands. Prada, 'was founded in 1913 in Milan. It offers men's and women's clothing, leather goods, footwear, eyewear and fragrances and Made to Measure service (Prada. Official Webside, 2020)'. Armani 'is an Italian luxury fashion house founded by Giorgio Armani which designs, manufactures, distributes and retails haute couture, ready-to-wear, leather goods, shoes, watches, jewellery, accessories, eyewear, cosmetics and home interiors' (Wikipedia: Armani, 2019a). Versace 'is an Italian luxury fashion company and trade name founded by Gianni Versace in 1978' (Wikipedia: Versace, 2019b).

"Emily, looking remarkably haggard and sloppy in a fitted but wrinkled sheer white T-shirt and hypertrendy cargo pants, was waiting for me in the reception area (...)" (p.37). This textual fragment refers to the appearance of Emily (the protagonist), Miranda's first assistant (the antagonist). Working for her boss was a really hard issue and constant stress for most of her workers. Epithet haggard means 'to look like being ill or tired, having dark circles under eyes' (Cambridge English Dictionary, 2020). Epithet sloppy means 'looking with a lack of neatness, order, a bit untidy' (The Free Dictionary, 2020). These stylistic devices reveals the real state of affairs in an office, where the main thing for the stuff was to survive. In addition, Emily was wearing a T-shirt, which looked as if it was not ironed, and cargo trousers with big pockets from the outside of the thighs. Epithet hypertrendy which means extremely trendy and sounds like bitter irony, as the character is extremely tired, but still extremely trendy.

- "I had never seen women with such radiant blond hair, didn't know that those brand-name highlights cost six grand a year to maintain or that others in the know could identify the colourists after a quick glance at the finished product" (p. 8). In this textual fragment radiant blond is a new type of hair treatment that make it nourished and healthy, with a nice shine. Some lightened strands of the hair are called highlights. Andrea emphasizes that the hairstyles of the employees were very well groomed and financed, because the costs of keeping the hair in order were not insignificant. Interestingly, some people have come to such an experience that they have been able to tell who was responsible for the hairdo.

"She was so perfectly tanned and manicured and exposed in such a way that normal people are not when there's snow on the ground" (p.18). This textual fragment shows how Miranda's employees showed their values in an almost comical way for an ordinary person. Normally, people hardly ever wear sandals in winter, even inside. One of the girls looked like in the middle of summer with tanned skin and almost bare legs. After all, in Runaway publishing house nobody was shocked by such an outfit.

"The driver took me to the private salon, where an older saleswoman whose facelift had left her eyes looking like slits (...)” (p.45). Another new word is connected with modern face treatment. Facelifting (lifting, face retouching) is one of the most popular plastic surgery procedures. The surgeon "smoothed" the face by removing excess skin, subcutaneous tissue and tightening the fascia (Facelifting, 2020).

So the novel "The Devil Wears Prada" by Lauren Weisberger which has the key features of a chick lit genre has been filled with new vocabulary related to femininity. On almost every page you can find some references to outfits, cosmetics or make-up (e.g. "a leather Louis Vuitton key chain from her Gucci logo tote", "The gorgeous jewellery and impeccable makeup", "She was so perfectly tanned and manicured"). 
Concerning the nouns in the text, they are all concrete, not abstract. Abstract words would not fit to a description of the city and the fashion house the characters are living, which is described in a very direct way. The text is written about facts, not about abstract things. The majority of the nouns refers to places, shopping and people: shoes, clothes, women, beauty, fasion. The analysed lexical nominations are neologisms which name the key objects of the world, which is guided by fashion industry, where a great emphasis is put on modern appearance and new modern procedures of keeping it young and perfect, making the image of a modern wise woman exact and new.

\section{Stylistic devices of revealing the image of a wise woman in a postmodern literary text}

Stylistic analysis in linguistics refers to the identification of patterns of usage in speech and writing. In some forms of stylisticanalysis, the numerical recurrence of certain stylistic features is used to make judgments about the nature and the quality of the writing.Among many techniques and terms we use while doing a stylistic analysis, foregrounding is particularly important in stylistic analysis. Leech and Short define foregrounding as an 'artistically motivated deviation'. According to Mukarovsky, foregrounding, the opposite of automaticity in a text, refers to the range of stylistic effects that occur in literature, whether at the phonetic level (e.g., alliteration, rhyme), the grammatical level (e.g., inversion, ellipsis), or the semantic level (e.g., metaphor, irony) all of which violate the scheme of the text. While studying a literary text from a stylistic perspective, we should start reading the text to understand the overall picture. Then, we should start dissecting the text by looking at peculiar and eye-catching peculiarities.

As to the stylistic devices used in the novel their stylistic role is to help to define the image of a wise woman presented in the analysed novel. At this point, we would like to give some examples and to analyse them.

"After the requisite look-over, Knockout Girl led me to Cheryl Kerston's office, Runway's executive editor and all-around lovable lunatic" (p.18). In the general meaning a lunatic is a person who is either mentally ill or behaves in a way that is dangerous or silly. By adding epithets all-around lovable the author created a metaphoric image of a special atmosphere of the office, which we can understood as being so delighted with the surrounding reality that for other people it seems to be an unhealthy fascination. And indeed, Miranda's employees often gave the impression that everything was great, hence their motto-hyperbole 'A million girls would die for this job'. But sometimes it seemed to be just a common consolation aimed at silencing real feelings.

- "The gorgeous jewellery and impeccable makeup of the human resources receptionist (...)" (p.13). As we have already mentioned before, the publishing house was filled with employees with the look of models who love fashion, stylish clothes, accessories and perfect make-up. The jewellery and make-up of one of the receptionists is described here with the help of epithets gorgeous and impeccable, because the general look of the representatives of the publishing house should be always be excellent.

- "She looked dynamite" (p.139). This metaphor refers to the main character, a modern businesswoman, Miranda. This metaphor does not realise its general feature that she looked like a dynamite stick ready to explode. With the help of this stylistic device Andy emphasizes that she looked very energetic, attractive and tempting. 
- "Bags and shoes I'd never seen on real people shouted Prada! Armani! Versace! (...)" (p.8). In this textual fragment the author uses personification, prescribing human features to unhuman ones, as in fact, neither shoes nor handbags are used to shout. Here, the inanimate objects are assigned a feature that is usually a human one. This personification made the emphasis on the fact that in the Elias-Clark building branded clothing and accessories, signed with the names of famous designers, are common, in fashion and appeared all the time, which was difficult to overlook.

- “(...) I'm sure a million girls would die for this job" (p. 17). This hyperbole undoubtedly appears most frequently in the whole analysed literary text. It shows that working with Miranda is a blue dream for every girl who is eager to work in a fashion industry. In fact, it was rather a consolation in some situations where employees could no longer cope with their dictatorial and powerful boss and were ready to die because of high psychological pressure. In fact, the job at her place was not very pleasant and most people worked there for a sense of high social status.

- "Emily swore that her tights had a 'wider circumference that a giant sequoia", (p.174). In this textual fragment the thing is that the runway employees, although very thin and tall, were still on a diet and controlled what they ate as well as their weight. Simile her tights had a 'wider circumference that a giant sequoia describes Emily's legs as they are wider than the trunk of a sequoia, which is a great exaggeration, considering that she was almost skinny.

- “What are they feeding y'all at Runway, huh?” (p.69). At the beginning of her new career, on her free day, Andy visited her family. Her sister, Jill, also came with her husband, Kyle. The above rhetorical question was spoken by Kyle. Its stylistic function is to emphasize that a girl looked extraordinarily slim, which could have been influenced by working in fashion industry, and in a famous fashion magazine in particular.

So, the stylistic devices that help to depict the image of a contemporary wise woman in a literary postmodern text, based on Lauren Weisberger's novel, we distinguish that the most frequently used among them are the following: epithets, metaphors, personifications, hyperboles, and rhetorical questions.

\section{Conclusions and suggestions}

Based on the analysis of the novel The Devil Wears Prada by Lauren Weisberger, we came to the conclusion that a modern wise woman has the following features: she takes care of her education and professional position. Achieving her own success is a priority for her. She is able to combine family and social life with self-development. She is not financially dependent on her boyfriend or husband, so they create a partnership. She spends her free time meeting friends as well as devoting it to her interests and beautifying activities, such as a visit to a beautician or a hairdressing salon. Thanks to this, a wise woman is satisfied and fulfilled in life.

As to the lexical means of revealing the image of a wise woman we may sum up that among them we distinguish neologisms, which denote famous brands, outfits, cosmetics or make-up. Among stylistic devices we assume that epithets, hyperbole, metaphors, personifications, and similes are the most frequently used in the novel under analysis. 


\section{References}

Babelyuk, O. (2018). Creating A Psychological Portrait Of A Postmodern Character In English Literary Text. Odessa linguistic journal, No. 11. DOI: 10.32837/2312-3192-2018-113-1.1. [in English].

Babelyuk, O., \& Galaidin, A. (2018). The DAO of Ecotranslation in Polish and Ukrainian translation studies. Scientific Journal of Polonia University, 28(3), 91-100. DOI: 10.23856/2811. [in English].

Baldick, Ch. (2001). The Concise Oxford Dictionary of Literary Terms. Oxford: Oxford University Press. [in English].

Cambridge English Dictionary. (2020). Online dictionary. [Electronic resource]. Retrieved from https://dictionary.cambridge.org/dictionary/english. [in English].

Collins Dictionary. (2020). Online dictionary. [Electronic resource]. Retrieved from https://www.collinsdictionary.com/dictionary/english. [in English].

Facelifting. (2020). Dom Lekarski. [Electronic resource]. Retrieved from https://domlekarski.pl/zabiegi/face-lifting/. [in English].

Fielding, H. (1996). Bridget Jones's Diary. Cover. New York: Viking. [in English].

Forster, E. M. (2005). Aspects of The Novel. Cambridge: Penguin Books. [in English].

Jung, G.C. (1930). Psychology and literature. Essay. [in English].

Prada. (2020). Official Webside. [Electronic resource]. Retrieved from https://www.prada.com. [in English].

Smith, Caroline J. (2008). Cosmopolitan Culture and Consumerism in Chick-Lit. New York: Routledge. [in English].

The Free Dictionary. (2020). Online dictionary. [Electronic resource]. Retrieved from https://www.thefreedictionary.com/sloppy. [in English].

Weisberger, L. (2003). The Devil Wears Prada. London: Harper Collins Publishers. [in English].

Weisberger, L. (2003). The Devil Wears Prada. London: Harper Collins Publishers. [in English].

Wikipedia. (2019). Free encyclopedia. E. M. Forster. [Electronic resource]. Retrieved from https://pl.wikipedia.org/wiki/E.M._Forster. [in Polish] .

Wikipedia. (2020a). Free encyclopedia. Armani. [Electronic resource]. Retrieved from https://en.wikipedia.org/wiki/Armani. [in English].

Wikipedia. (2020b). Free encyclopedia. Versace. [Electronic resource]. Retrieved from https://en.wikipedia.org/wiki/Versace. [in English]. 